\title{
Chelation in Metal Intoxication XV: Influence of Dimercaptopropane Sulphonate (DMPS) on Lead Poisoned Rats with Normal or Damaged Kidneys
}

\author{
Swaranjeet S. FLORA and Sushil K. TANDON \\ Industrial Toxicology Research Centre, Post Box 80, \\ Lucknow-226 001, India.
}

(Received June 29, 1984)

\begin{abstract}
The efficacy of 2, 3 dimercaptopropane 1, sulphonate (DMPS) to enhance urinary excretion of lead, reduce the concentration of $\mathrm{Pb}$ in blood, brain, kidneys and liver and restore $\mathrm{Pb}$ induced alterations in the activities of renal and blood enzymes and brain biogenic amines in rats with normal or experimentally damaged kidneys, was investigated. The acute renal damage was induced by uranyl acetate prior to treatment with DMPS. The chelating agent was effective in reducing body burden of $\mathrm{Pb}$ by enhancing its excretion and in restoring biological alterations, more markedly in animals with normal kidneys than in those with acutely damaged kidneys. However, the increased brain concentration of $\mathrm{Pb}$ and altered levels of brain catecholamines remained unaffected on treatment with DMPS.
\end{abstract}

Key words: DMPS-Lead toxicity-Uranyl acetate-Enzyme-Kidney-Rat

\section{INTRODUCTION}

Kidney is the target organ for lead effects. The investigations suggest the presence of kidney damage, as measured by blood urea nitrogen (BUN), creatinine and clearence studies in workers with a history of lead exposure and with blood lead generally in the range of $60-80 \mu \mathrm{g} / 100 \mathrm{ml} \cdot{ }^{1-4)}$ Cooper and Gaffey ${ }^{5)}$ found an increased risk of death from chronic and unspecified nephritis among workers exposed to lead.

The experience with the treatment of lead poisoning by some well known heavy metal chelators such as calcium versenate (Ca EDTA) and 2,3-dimercaptopropanol (BAL) has raised serious doubts about their prophylactic use in humans particularly with existing renal dysfunction owing to their undesirable effects. 2,3-Dimercaptopropane 1, sulphonate (DMPS, Unithiol), a water soluble derivative of BAL has been suggested to be an effective alternate for the treatment of lead poisoning. ${ }^{6}$ ) However, the efficacy and safety of the compound might greatly depend on the renal condition. With a view to ascertain the suitability of DMPS for the treatment 
of lead poisoning in individuals with renal dysfunction, caused either by lead itself or some other factors, the effect of DMPS on lead intoxicated rats with normal and experimentally damaged kidneys was investigated.

\section{Materials AND Methods}

Male albino rats weighing $150 \pm 10 \mathrm{~g}$ of ITRC colony maintained on standard pellet diet (Hindustan Lever Ltd., India) and water ad libitum were administered $10 \mathrm{mg} / \mathrm{kg}, \mathrm{Pb}$ as $\mathrm{Pb}\left(\mathrm{OCOCH}_{3}\right)_{2} .3 \mathrm{H}_{2} \mathrm{O}$ dissolved in water, orally for four weeks. The animals receiving water alone served as normal control. Lead treated rats were divided equally into two groups. The animals of group I were given single injection of uranyl acetate $(3 \mathrm{mg} / \mathrm{kg}$, s.c.) and those of group II received an equivalent amount of sodium acetate. Six animals from each group and 6 normal controls were kept individually in metabolic cages for $24 \mathrm{hr}$ urine collection in ice cold tubes for 3 days. All the normal controls and six animals from groups I and II were decapitated on the 4th day. Kidneys, liver and brain were removed and blood was collected from the heart in heparinized tubes.

Half of the remaining rats in groups I and II were administered DMPS (0.3 $\mathrm{m}$ mole $(63 \mathrm{mg}) / \mathrm{kg}$, i.p. 2 doses $8 \mathrm{hr}$ apart) dissolved in normal saline and the other half received an equal volume of saline alone. Six animals, after each treatment, were kept in metabolic cages for $24 \mathrm{hr}$ urine collection for 4 days. Tissue and blood were collected thereafter.

Standard procedures were used to determine the activities of lactic dehydrogenase $(\mathrm{LDH})^{7)}$, glutamic oxalacetic transaminase $(\mathrm{GOT})^{8)}$ and alkaline phosphatase $(\mathrm{ALP})^{9)}$ in urine and kidney homogenate $(10 \%, \mathrm{w} / \mathrm{v})$. The excretion of $\delta$ aminolevulinic acid ( $\delta$-ALA) was measured in the last urine sample using the method of Davis et al. ${ }^{10)}$ The activity of blood $\delta$-aminolevulinic acid dehydratase $(\delta \text {-ALAD })^{11)}$ hemoglobin $(\mathrm{Hb}),{ }^{12)}$ packed cell volume $(\mathrm{PCV})^{13)}$ and Zinc protoporphyrin (ZPP) ${ }^{14)}$ levels were measured immediately after collection. The levels of dopamine (DA), norepinephrine (NE) and 5-hydroxytryptamine (5-HT) were estimated in brain. ${ }^{15}$ )

Lead was estimated in urine, ${ }^{16)}$ blood, ${ }^{17)}$ kidneys, liver and brain ${ }^{18)}$ following wet acid digestion using atomic absorption spectrophotometer (Perkin Elmer $5,000)$.

\section{RESULTS}

Exposure to $\mathrm{Pb}$ for four weeks significantly increased blood, kidney, liver and brain concentrations of $\mathrm{Pb}$, blood $\mathrm{ZPP}$, urinary $\delta$-ALA, inhibited the activities of blood $\delta$-ALAD, renal LDH, GOT, ALP and decreased the blood Hb. Lead also decreased the levels of brain DA and 5-HT and increased that of brain NE (Table 1). The urinary excretion of $\mathrm{Pb}$ increased and that of $\mathrm{LDH}$, GOT and 
Table 1. Effect of uranyl acetate on $\mathrm{Pb}$ induced alterations in rats

\begin{tabular}{|c|c|c|c|}
\hline \multirow{2}{*}{ Parameters } & \multirow{2}{*}{$\begin{array}{l}\text { Normal } \\
\text { control }\end{array}$} & \multicolumn{2}{|c|}{ Administration after $\mathrm{Pb}$ exposure } \\
\hline & & Sodium acetate & Uranyl acetate \\
\hline \multicolumn{4}{|l|}{ Blood } \\
\hline $\mathrm{Pb}(\mu \mathrm{g} / 100 \mathrm{~m} l)$ & $12.6 \pm 0.90$ & $116.3 \pm 10.10^{a)}$ & $131.3 \pm 12.10^{\mathrm{a})}$ \\
\hline $\begin{array}{l}\delta \text {-ALAD ( } \mu \text { mole } \delta \text {-ALA } / \mathrm{min} / \\
\text {-erythorocyte) }\end{array}$ & $4.6 \pm 0.30$ & $1.9 \pm 0.20^{a)}$ & $0.8 \pm 0.30^{a) * *}$ \\
\hline $\mathrm{Hb}(\mathrm{g} / 100 \mathrm{ml})$ & $13.4 \pm 0.70$ & $10.1 \pm 0.30^{\mathrm{b})}$ & $9.4 \pm 0.50^{\mathrm{a})}$ \\
\hline PCV ( $\%$ volume) & $44.7 \pm 0.40$ & $45.0 \pm 1.10$ & $42.8 \pm 1.70$ \\
\hline $\mathrm{ZPP}(\mu \mathrm{g} \mathrm{ZPP} / \mathrm{g}, \mathrm{Hb})$ & $2.1 \pm 0.40$ & $7.1 \pm 0.70^{\mathrm{a})}$ & $\left.10.3 \pm 0.30^{a}\right) * *$ \\
\hline \multicolumn{4}{|l|}{ Urine } \\
\hline$\delta$-ALA $(\mathrm{mg} / 100 \mathrm{ml})$ & $0.1 \pm 0.01$ & $\left.0.3 \pm 0.01^{a}\right)$ & $\left.0.3 \pm 0.04^{a}\right)$ \\
\hline \multicolumn{4}{|l|}{ Kidney } \\
\hline $\mathrm{Pb}(\mu \mathrm{g} / \mathrm{g}$, fresh tissue $)$ & $4.4 \pm 0.80$ & $16.7 \pm 1.10^{\mathrm{a})}$ & $25.3 \pm 1.90^{\mathrm{a})} * *$ \\
\hline $\begin{array}{l}\text { LDH ( } \mu \text { mole NADH oxidized/ } \\
\text { min } / \mathrm{mg} \text { protein) }\end{array}$ & $3.8 \pm 0.50$ & $2.1 \pm 0.30^{\mathrm{b})}$ & $\left.1.1 \pm 0.20^{a}\right) * *$ \\
\hline $\begin{array}{l}\text { GOT (n mole hydrazone } \\
\text { formed } / \mathrm{min} / \mathrm{mg} \text { protein) }\end{array}$ & $28.3 \pm 1.30$ & $24.7 \pm 1.30^{\mathrm{c})}$ & $17.3 \pm 1.90^{a) * *}$ \\
\hline $\begin{array}{l}\text { ALP }(\mu \text { mole phenol } \\
\text { liberated } / \mathrm{min} / \mathrm{mg} \text { protein })\end{array}$ & $1.4 \pm 0.03$ & $0.8 \pm 0.04^{a}$ & $0.4 \pm 0.09 a) * *$ \\
\hline \multicolumn{4}{|l|}{ Liver } \\
\hline $\mathrm{Pb}(\mu \mathrm{g} / \mathrm{g}$, fresh tissue $)$ & $4.7 \pm 0.90$ & $30.1 \pm 1.70^{a)}$ & $31.3 \pm 1 \cdot 90^{\text {a) }}$ \\
\hline \multicolumn{4}{|l|}{ Brain } \\
\hline $\mathrm{Pb}(\mu \mathrm{g} / \mathrm{g}$, fresh tissue $)$ & $0.5 \pm 0.03$ & $3.1 \pm 0.04^{\mathrm{a})}$ & $3.1 \pm 0.07 a)$ \\
\hline $\mathrm{DA}(\mu \mathrm{g} / \mathrm{g}$, fresh tissue $)$ & $0.41 \pm 0.02$ & $0.36 \pm 0.01^{c)}$ & $0.35 \pm 0.20^{(\mathrm{c})}$ \\
\hline $\mathrm{NE}(\mu \mathrm{g} / \mathrm{g}$, fresh tissue $)$ & $0.24 \pm 0.01$ & $0.28 \pm 0.02^{c)}$ & $0.27 \pm 0.00^{\mathrm{c})}$ \\
\hline 5-HT $(\mu \mathrm{g} / \mathrm{g}$, fresh tissue $)$ & $0.48 \pm 0.01$ & $0.04 \pm 0.00^{\mathrm{c})}$ & $0.43 \pm 0.01 \mathrm{c})$ \\
\hline
\end{tabular}

Each figure is mean \pm S.E. of 6 samples

a) $\mathrm{p}<0.001$, b) $\mathrm{p}<0.01$, c) $\mathrm{p}<0.05$, versus normal control; ** $\mathrm{p}<0.01$ versus sodium acetate administered group, as evaluated by the student's ' $t$ ' test.

ALP remained within normal range at the end of four weeks of $\mathrm{Pb}$ exposure (Fig. 1). However, single s.c. injection of uranyl acetate enhanced the urinary excretion of $\mathrm{LDH}$, GOT and ALP, further increased the concentration of $\mathrm{Pb}$ and inhibited the activities of these enzymes in kidneys showing acute renal damage (Fig. 1, Table 1). Uranyl acetate also enhanced the $\mathrm{Pb}$ induced inhibition in the activity of blood $\delta$-ALAD and elevation of blood ZPP level (Table 1).

DMPS was effective in enhancing urinary excretion of $\mathrm{Pb}$ and in reducing urinary $\delta$-ALA. The effects were more marked in animals with normal kidneys than in those with damaged kidneys (Fig.2 and 3). The level of renal $\mathrm{Pb}$ increased and that of hepatic $\mathrm{Pb}$ decreased with time after cessation of $\mathrm{Pb}$ exposure without treatment with DMPS. However, DMPS lowered blood, renal, and hepatic $\mathbf{P b}$ levels; the renal depletion being significantly more marked in animals with normal kidneys (Table 2). The treatment with DMPS restored lead induced inhibition in the activity of blood $\delta$-ALA-D and elevation of blood ZPP more effectively in animals with normal kidneys (Table 3 ).

The chelating agent however, failed to restore the lead induced alterations in 


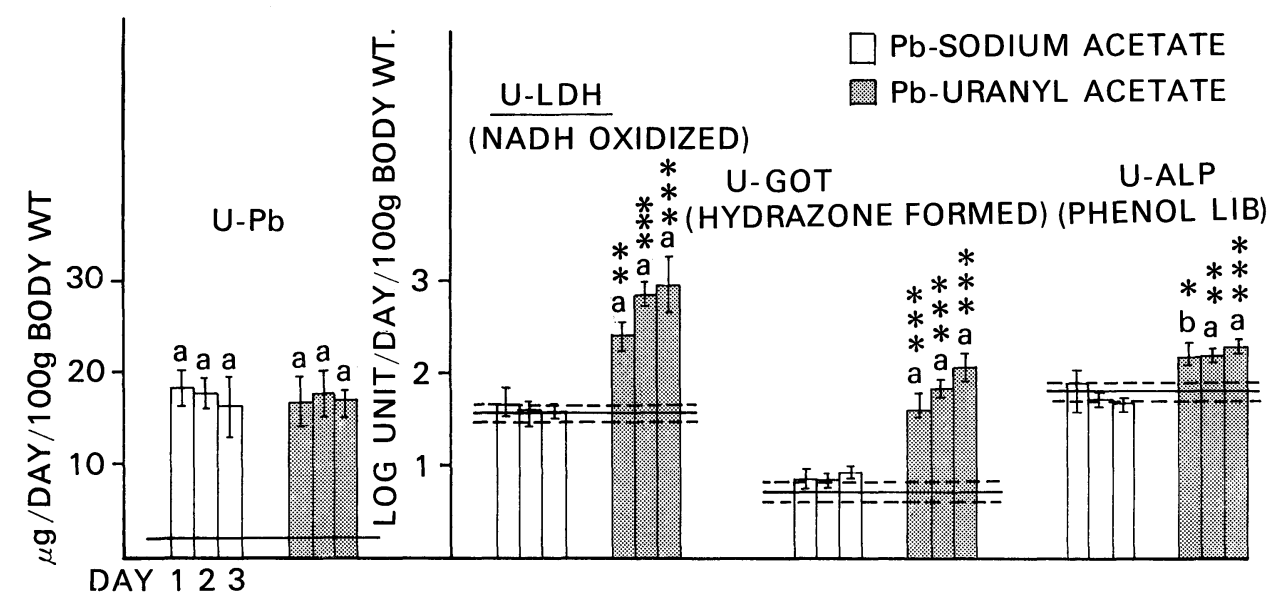

Fig. 1. Effect of uranyl acetate on urinary excretions of $P b$ and enzymes in $P b$ preexposed rats.

Each bar represents mean \pm S.E. of 6 values. Horizontal lines represent normal control (mean \pm S.E. of 6 values) a) $\mathrm{p}<0.001$, b) $\mathrm{p}<0.01$, versus normal control $* * * \mathrm{p}<0.001, * * \mathrm{p}<0.01, * \mathrm{p}<0.05$ versus $\mathrm{Pb}$-sodium acetate administered group as evaluated by the student's ' $t$ ' test.

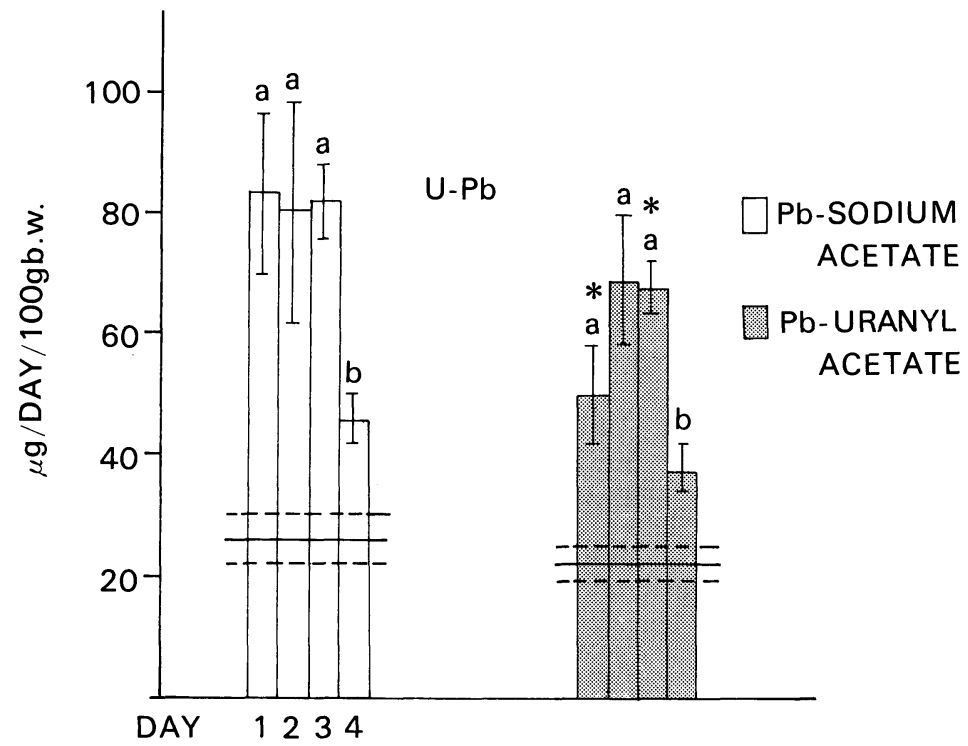

Fig. 2. Effect of DMPS on urinary excretion of $P b$ in $P b$ poisoned rats.

Each bar represents mean \pm S.E. of 6 values. Horizontal lines represent respective saline control. a) $\mathrm{p}<0.001$, b) $\mathrm{p}<0.01$ versus saline control; $* \mathrm{p}<0.05$ versus sodium acetate administered group as evaluated by the students's ' $t$ ' test. 


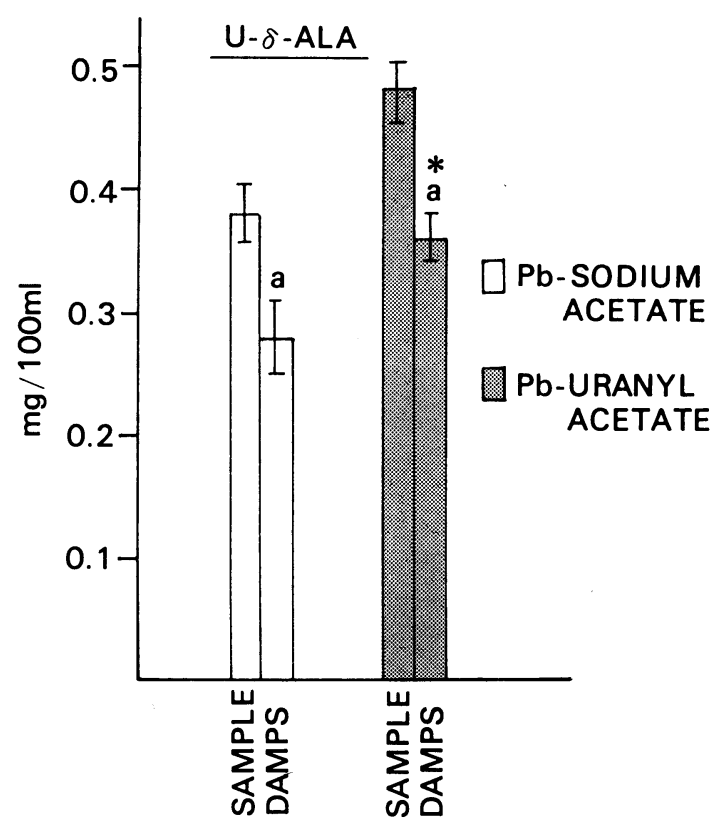

Fig. 3. Effect of DMPS on urinary excretion of $\delta$-ALA in $\mathrm{Pb}$ poisoned rats on the 4th day.

Each bar represents mean \pm S.E. of 6 values. a) $\mathrm{p}<0.001$ versus saline control; ${ }^{*} \mathrm{p}<0.05$ versus $\mathrm{Pb}$-sodium acetate administered group as evaluated by the student's ' $t$ ' test.

Table 2. Effect of DMPS on the blood and tissue levels of $\mathbf{P b}$ in lead poisoned rats

\begin{tabular}{|c|c|c|c|c|}
\hline & \multicolumn{2}{|c|}{ Pb-sodium acetate } & \multicolumn{2}{|c|}{ Pb-uranyl acetate } \\
\hline & saline & DMPS & saline & DMPS \\
\hline Blood $t$ & $103.79 \pm 8.15$ & $\frac{\left.80.46 \pm 6.74^{(}\right)}{(5)}$ & $\frac{123.24 \pm 6.58}{(5)}$ & ${ }_{(5)}^{\left.82.43 \pm 10.11^{(}\right)}$ \\
\hline Kidneytt & $26.84 \pm 1.19$ & $\begin{array}{c}8.22 \pm 1.06^{\mathrm{a})} \\
(5)\end{array}$ & $29.61 \pm \underset{(5)}{ \pm 1.92}$ & $\underset{(5)}{13.99 \pm 1.32^{\mathrm{b}) *}}$ \\
\hline Livertt & $10.12 \pm 0.83$ & $\begin{array}{c}5.97 \pm 0.61^{\mathrm{b})} \\
(5)\end{array}$ & $\underset{(5)}{10.36 \pm 1}$ & $\frac{6.39 \pm 1.23^{b)}}{(5)}$ \\
\hline Braintt & $\begin{array}{c}2.88 \pm 0.53 \\
(4)\end{array}$ & $\begin{array}{c}3.16 \pm 0.40 \\
(5)\end{array}$ & $\begin{array}{c}2.81 \pm 0.44 \\
(5)\end{array}$ & $\begin{array}{c}3.12 \pm 0.21 \\
(4)\end{array}$ \\
\hline
\end{tabular}

$\dagger \mu \mathrm{g} / 100 \mathrm{~m} l ; \dagger \mu \mathrm{g} / \mathrm{g}$, fresh tissue.

Each figure is mean \pm S.E. of number of samples given in parenthesis: a) $p<0.001$, b) $\mathrm{p}<0.01$, c) $\mathrm{p}<0.05$ versus saline control; * $\mathrm{p}<0.05$ versus corresponding Pb-sodium acetate administered group as evaluated by the student's ' $t$ ' test.

the levels of brain $\mathrm{Pb}$, biogenic amines and the activities of renal enzymes irrespective of renal condition (Tables 2, 4 and 5). 
Table 3. Effect of DMPS on $\mathrm{Pb}$ induced alterations in blood parameters in rats

\begin{tabular}{|c|c|c|c|c|}
\hline & \multicolumn{2}{|c|}{ Pb-sodium acetate } & \multicolumn{2}{|c|}{ Pb-uranyl acetate } \\
\hline & saline & DMPS & saline & DMPS \\
\hline$\delta$-ALAD $\dagger$ & $3.16 \pm 0.53$ & $5.50 \pm 0.78^{b)}$ & $1.13 \pm 0.10$ & $2.99 \pm 0.52^{\mathrm{b}) *}$ \\
\hline ZPP†† & $6.86 \pm \frac{2.59}{(5)}$ & $3.74 \pm 0.84^{b)}$ & $12.10 \pm \frac{ \pm 1.91}{(5)}$ & $6.72 \pm 0.80^{\mathrm{a}) *}$ \\
\hline $\mathrm{Hbtti}$ & $10.35 \pm 0.46$ & $10.50 \pm 0.33$ & $10.32 \pm 0.38$ & $10.86 \pm 0.53$ \\
\hline PCVttit & $41.50 \pm \frac{1.25}{(5)}$ & $39.66 \pm 3.06$ & $39.75 \pm 2.42$ & $41.57 \pm 0.65$ \\
\hline
\end{tabular}

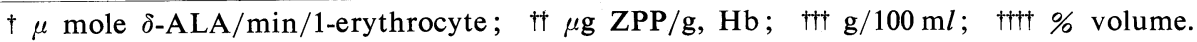
Each figure is mean \pm S.E. of number of samples given in parenthesis: a) $p<0.001$, b) $\mathrm{p}<0.01$ versus saline control $* \mathrm{p}<0.05$, versus corresponding $\mathrm{Pb}$-sodium acetate treated group as evaluted by the student's ' $t$ ' test.

Table 4. Effect of DMPS on $P b$ induced alterations in brain biogenic amines in rats

\begin{tabular}{lccccc}
\hline & \multicolumn{2}{c}{ Pb-sodium acetate } & & \multicolumn{2}{c}{ Pb-uranyl acetate } \\
\cline { 2 - 3 } \cline { 5 - 6 } & saline & DMPS & & saline & DMPS \\
\hline DA $\dagger$ & $0.35 \pm 0.03$ & $0.35 \pm 0.04$ & & $0.33 \pm 0.02$ & $0.34 \pm 0.02$ \\
NE $^{\dagger}$ & $0.27 \pm 0.01$ & $0.31 \pm 0.02$ & & $0.26 \pm 0.02$ & $0.26 \pm 0.03$ \\
5-HT $\dagger$ & $0.41 \pm 0.03$ & $0.46 \pm 0.03$ & & $0.50 \pm 0.05$ & $0.44 \pm 0.01$ \\
\hline
\end{tabular}

Each figure is mean \pm S.E. of 5 samples.

$\dagger \mu \mathrm{g} / \mathrm{g}$, fresh tissue.

Table 5. Effect of DMPS on $P b$ induced alterations in renal enzymes in rats

\begin{tabular}{|c|c|c|c|c|}
\hline & \multicolumn{2}{|c|}{ Pb-sodium acetate } & \multicolumn{2}{|c|}{$\mathrm{Pb}$-uranyl acetate } \\
\hline & saline & DMPS & saline & DMPS \\
\hline $\mathrm{LDH}^{\dagger}$ & $1.58 \pm 0.12$ & $1.78 \pm 0.14$ & $1.03 \pm 0.14$ & $1.11 \pm 0.06^{* *}$ \\
\hline GOT† & $30.14 \pm 2.06$ & $32.09 \pm 2.59$ & $16.34 \pm 2.77$ & $17.80 \pm 1.48^{* *}$ \\
\hline ALPttt & $0.83 \pm 0.17$ & $0.71 \pm 0.02$ & $0.44 \pm 0.02$ & $0.42 \pm 0.01^{* *}$ \\
\hline
\end{tabular}

$\dagger \mu$ mole NADH oxidized $/ \mathrm{min} / \mathrm{mg}$ protein; it $\mathrm{n}$ mole of hydrazone formed $/ \mathrm{min} / \mathrm{mg}$ protein; tt† $\mu$ mole phenol liberated $/ \mathrm{min} / \mathrm{mg}$ protein. Each figure is mean $\pm \mathrm{S}$.E. of 6 samples; ** $\mathrm{p}<0.01$ versus corresponding $\mathrm{Pb}$-sodium acetate treated group as evaluated by students ' $t$ ' test.

\section{Discussion}

DMPS was effective in enhancing the urinary excretion of $\mathrm{Pb}$, in lowering blood and tissue concentrations of $\mathrm{Pb}$, reducing $\mathrm{Pb}$ induced urinary excretion of $\delta$-ALA and in restoring the decreased activity of blood $\delta$-ALA-D in rats which show its ability to form readily excretable complex with $\mathrm{Pb}$ in vivo. These effects were more marked in animals exposed to $\mathrm{Pb}$-sodium acetate than in those exposed to $\mathrm{Pb}$-uranyl acetate, showing comparatively poor elimination of $\mathrm{Pb}$ from the animals 
with renal dysfunction. This may be explained by a) The blood supply in damaged kidneys would be poor and therefore, less chelating agent would reach the renal tissue to mobilize $\mathrm{Pb}$ into urine as urinary pathway is the main route of $\mathrm{Pb}$ elimination from the body. This is apparently true as blood levels of $\mathrm{Pb}$ decreased more markedly in rats with normal kidneys than in those with acutely damaged kidneys after cessation of $\mathrm{Pb}$ exposure before treatment with DMPS (Compare Tables 1 and 2); b) Due to kidney damage the renal clearance of $\mathrm{Pb}$ would be adversely affected and its retention would increase. This is supported by the fact that renal concentration of $\mathrm{Pb}$ was significantly higher in rats exposed to $\mathrm{Pb}$-uranyl acetate than in those exposed to $\mathrm{Pb}$-sodium acetate (Table 1) and c) The proximal tubular damage by uranyl acetate will lead to increased reabsorption of $\mathrm{Pb}$ during mobilization by DMPS resulting in lower elimination and higher retention of $\mathrm{Pb}$ in the renal tissue, which is indicated by comparatively less elimination of renal $\mathrm{Pb}$ in $\mathrm{Pb}$-uranyl acetate exposed animals than in those exposed to $\mathrm{Pb}$-sodium acetate (Table 2). However, no significant difference could be observed in the removal of hepatic-Pb by DMPS between rats with normal and damaged kidneys. ${ }^{19}$ )

The results show DMPS to be an effective chelating agent for the treatment of $\mathrm{Pb}$ intoxication, irrespective of the renal funciton. However, supportive therapy for renal damage may be necessary to achieve optimum effect of DMPS in patients of $\mathrm{Pb}$ poisoning with renal dysfunction. As the increased brain level of $\mathrm{Pb}$ and altered levels of brain catecholamines remained unaffected on treatment with DMPS, the chelating agent has apparently failed to cross the blood-brain barrier or reach the neuronal site of lead accumulation. ${ }^{20)}$

\section{ACKNOWLEDGEMENT}

Authors are grateful to Indian Council of Medical Research, New Delhi for the award of Research fellowship to S. J. S. Flora. Thanks are due to Messrs. S. Singh and V. K. Jain for the technical assistance.

\section{REFERENCES}

1) Baker, E. L., Landrigan, P. J., Barbour, A. G., Cox, D. H., Folland, D. S., Ligo, R. N. and Throckmorton, J. (1979). Occupational lead poisoning in the United States: Clinical and biochemical findings related to blood lead levels, Brit. J. Indust. Med., 36, 314.

2) Lilis, R., Fischbein, A., Diamond, S., Anderson, H. A., Selikoff, I. J., Blumberg, W. E. and Eisinger, J. (1977). Lead effects among secondary lead smelter workers with blood levels below $80 \mu \mathrm{g} / 100 \mathrm{ml}$, Arch. Environ. Health, 32, 256.

3) Lilis, R., Fischbein, A., Eisinger, J., Blumberg, W. E., Diamond, S., Anderson, H. A., Rom, W., Rice, C., Sarkozl, L., Kon, S. and Selikoff, I. J. (1977). Prevalence of lead disease among secondary lead smelter workers and biological indicators of lead exposure, Environ. Res., 14, 255.

4) Wedeen, R. P., Dipak, K. M. and Batuman, V. (1979). Detection and treatment of 
occupational lead nephropathy, Arch. Intern. Med., 139, 53.

5) Cooper, W. C. and Gaffey, W. R. (1975). Mortality of workers in lead smelters and lead battery plants, J. Occ. Med., 17, 100.

6) Twarog, T. A. and Cherian, M. G. (1983). Chelation of lead with DMPS and BAL in rats injected with lead, Bull. Environ. Contam. Toxicol., 30, 165.

7) Wooton, I. D. P. (1964). Lactate dehydrogenase, spectrophotometric method. In: Microanalysis in Medical Biochemistry (E. J. King, ed.), 4th edn, p. 115, J \& A Churchill, London.

8) Reitman, S. and Frankel, S. (1957). A colorimetric method for the determination of serum glutamic oxalacetic and glutamic pyruvic transaminases, Am. J. Clin. Pathol., 28, 56.

9) Wright, P. J., Leathwood, P. D. and Plummer, D. T. (1972). Enzymes in rat urine: Alkaline phosphatase, Enzymologia, 42, 317.

10) Davis, J. R., Abrahams, R. H., Fishbein, W. I. and Fabrega, E. A. (1968). Urinary delta aminolevulinic acid (ALA) levels in lead poisoning II. Correlation of ALA values with clinical findings in 250 children with suspected lead ingestion, Arch. Environ. Health, $17,164$.

11) Berlin, A. and Schaller, K. H. (1974). European standardized method for the determination of $\delta$-aminolevulinic acid dehydratase activity in blood, Z. Klin. Chem. Klin. Biochem., $12,389$.

12) Clegg, J. W. and King, K. J. (1942). Estimations of hemoglobin by the alkaline haematin method, Brit. Med. J., 2, 329.

13) Keele, C. A. and Neil, E.(1966). In: Samsons Wright's Applied Physiology, 2nd ed. Oxford Medical Publication ELBS and Oxford University Press, p. 12.

14) Grandjean, P. (1979). Occupational lead exposure in Denmark: Screening with hematofluorometer, Brit. J. Ind. Med., 36, 52.

15) Sadvongvivad, C. (1977). Pharmacological significance of biogenic amines in the lung: 5-hydroxytryptamine, Brit. J. Pharmacol., 38, 353.

16) Kopito, L. and Schwachman, H. (1967). Determination of lead in urine by atomic absorption spectroscopy using coprecipitation with bismuth, J. Lab. Clin. Med., 70, 326.

17) Hessel, D. W. (1968). A simple and rapid quantitative determination of lead in blood, Atomic Absorption Newsletter, 7, 55.

18) Yeager, D. W., Cholak, J. and Henderson, E. W. (1971). Determination of lead in biological and related material by the atomic absorption spectrophotometry, Environ. Sci. Technol., 5, 1020.

19) Tandon, S. K., Flora, S. J. S. and Singh, Surendra (1985). Chelation in metal intoxication XIV: Effect of thiol and amino chelators in lead poisoned rats with normal or damaged kidneys, Toxicol. Appl. Pharmacol. in press.

20) Silbergeld, E. K. and Hruska, R. E. (1980). Neurochemical investigaitons of low level lead exposure, In: Low Level Lead Exposure: The clinical implications of current research, (Edited by H. L. Needleman), p. 135, Raven Press, New York. 